\title{
Defective exocytosis and processing of insulin in a cystic fibrosis mouse model
}

\author{
A Edlund1', M Barghouth², M Hühn³, M Abels4', J S E Esguerra1', I G Mollet'1, E Svedin³, A Wendt ${ }^{1}$, E Renström², \\ E Zhang2, N Wierup4, B J Scholte ${ }^{5,6}$, M Flodström-Tullberg 3 and L Eliasson1 \\ 1 Unit of Islet Cell Exocytosis, Lund University Diabetes Centre, Department of Clinical Sciences in Malmö, Lund University, Malmö, Sweden \\ 2Unit of Islet Pathophysiology, Lund University Diabetes Centre, Department of Clinical Sciences in Malmö, Lund University, Malmö, Sweden \\ ${ }^{3}$ Center for Infectious Medicine, Department of Medicine Huddinge, Karolinska Institutet, Karolinska University Hospital, Stockholm, Sweden \\ ${ }^{4}$ Unit of Neuroendocrine Cell biology, Lund University Diabetes Centre, Department of Clinical Sciences in Malmö, Lund University, Malmö, Sweden \\ 5Department of Cell Biology, Erasmus MC, Rotterdam, the Netherlands \\ ${ }_{6}^{6}$ Pediatric Pulmonology, Erasmus MC, Rotterdam, the Netherlands
}

Correspondence should be addressed to A Edlund or L Eliasson: anna.edlund@med.lu.se or lena.eliasson@med.lu.se

\begin{abstract}
Cystic fibrosis-related diabetes (CFRD) is a common complication for patients with cystic fibrosis (CF), a disease caused by mutations in the cystic fibrosis transmembrane conductance regulator (CFTR). The cause of CFRD is unclear, but a commonly observed reduction in first-phase insulin secretion suggests defects at the beta cell level. Here we aimed to examine alpha and beta cell function in the CftrtmlEUR/F508del mouse model (C57BL/6J), which carries the most common human mutation in CFTR, the F508del mutation. CFTR expression, beta cell mass, insulin granule distribution, hormone secretion and single cell capacitance changes were evaluated using islets (or beta cells) from F508del mice and age-matched wild type (WT) mice aged 7-10 weeks. Granular pH was measured with DND-189 fluorescence. Serum glucose, insulin and glucagon levels were measured in vivo, and glucose tolerance was assessed using IPGTT. We show increased secretion of proinsulin and concomitant reduced secretion of C-peptide in islets from F508del mice compared to WT mice. Exocytosis and number of docked granules was reduced. We confirmed reduced granular pH by CFTR stimulation. We detected decreased pancreatic beta cell area, but unchanged beta cell number. Moreover, the F508del mutation caused failure to suppress glucagon secretion leading to hyperglucagonemia. In conclusion, F508del mice have beta cell defects resulting in (1) reduced number of docked insulin granules and reduced exocytosis and (2) potential defective proinsulin cleavage and secretion of immature insulin. These observations provide insight into the functional role of CFTR in pancreatic islets and contribute to increased understanding of the pathogenesis of CFRD.
\end{abstract}

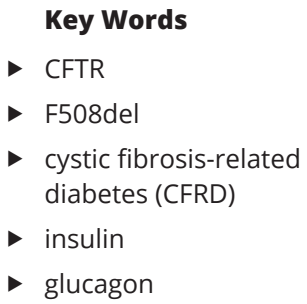

Journal of Endocrinology (2019) 241, 45-57

\section{Introduction}

Cystic fibrosis (CF) is an autosomal recessive disease caused by mutations in CFTR encoding the cystic fibrosis transmembrane conductance regulator (CFTR). CFTR is an anion channel that conducts $\mathrm{Cl}^{-}$and $\mathrm{HCO}_{3}{ }^{-}$and is activated by ATP and cAMP (Chen et al. 2010). Besides being an ion channel CFTR is a regulator of other ion channels and membrane proteins (Sheppard \& Welsh 1999). The F508del mutation in CFTR is carried by $65-80 \%$ https://joe.bioscientifica.com https://doi.org/10.1530/JOE-18-0570 (c) 2019 The authors Published by Bioscientifica Ltd. Printed in Great Britain

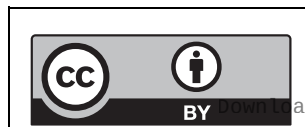

This work is licensed under a Creative Commons Attribution 4.0 Unported License. 
of people living with CF (Koivula et al. 2016). In both human and mouse, F508del-CFTR is misprocessed in the endoplasmatic reticulum and the channel is subsequently degraded. However, a small portion of F508del-CFTR escapes degradation and reaches the plasma membrane where it has reduced conductivity (Wilke et al. 2011).

Blood glucose abnormalities are common in CF and CF-related diabetes (CFRD) is a common secondary complication. Acquiring diabetes on the background of CF leads to an increased morbidity and mortality, and depending on the age-group studied $30-50 \%$ of the adult patients have CFRD (Brennan et al. 2004, Dobson et al. 2004, de Valk \& van der Graaf 2007). Deficient insulin secretion, beta cell dysfunction and various degrees of insulin resistance characterize CFRD (Hardin et al. 2008, Cano Megias et al. 2015). The pathogenesis in CFRD is still not completely understood. Patients with severe mutations in CFTR and pancreatic exocrine insufficiency are predictors of CFRD but pancreatic sufficient patients also acquire CFRD (Wooldridge et al. 2015). The question whether CFTR has a functional role in beta cells is not without controversy. We and others have shown that CFTR is expressed in primary human and rodent islet cells (Boom et al. 2007, Edlund et al. 2014, 2017, Guo et al. 2014, Huang et al. 2017). Moreover, single cell transcriptome analysis of human islets has revealed that CFTR mRNA is expressed in a subset of alpha and beta cells (Blodgett et al. 2015, Segerstolpe et al. 2016). However, on the basis of the single cell transcriptome analysis, others have argued that CFTR is not expressed at a significant level in the islet cells and therefore do not contribute to beta cell dysfunction in CF and CFRD (Sun et al. 2017, Hart et al. 2018). Instead, it has been suggested that CFRD is driven by a combination of beta cell loss, inflammation, islet remodeling and general morbidity (Sun et al. 2017, Hart et al. 2018). Loss of beta cell mass is implicated in CF but not to the extent seen in type 1 diabetes (Moran et al. 2010). Moreover, treatment with the CFTR corrector Ivacaftor restored beta cell function and insulin secretion in CF patients (Bellin et al. 2013, Kelly et al. 2019), indicating dysfunctional insulin secretion in CFRD.

Animal models resembling human CF have shed light on CFRD pathology. The newborn $\mathrm{Cftr}^{-1-}$ ferrets display reduced first-phase insulin secretion and glucose intolerance (Olivier et al. 2012). The CF pigs are born with pancreatic inflammation similar to humans. Islet cell mass is intact but when challenged with an intravenous glucose tolerance test, glucose tolerance is impaired with increased proinsulin to insulin secretion ratio (Uc et al. 2015). Increased proinsulin secretion suggests impaired processing of insulin and an intrinsic beta cell defect. Also pancreatic-insufficient CF patients have increased proinsulin to C-peptide secretion both during fasting and in glucose-stimulated conditions (Sheikh et al. 2017, Nyirjesy et al. 2018). Hence, suggesting that insulin processing might be impaired in human CF. Insulin maturation within the insulin granule requires cleavage of proinsulin by endopeptidases into mature insulin and C-peptide, a process that is dependent on an acidic intragranular environment (Davidson et al. 1988). Acidification of the granule is achieved by simultaneous pumping of $\mathrm{H}^{+}$and $\mathrm{Cl}^{-}$into the granule (Barg et al. 2001). Inadequate granular acidification results in an increased intragranular proinsulin to mature insulin ratio (Davidson et al. 1988). We have previously shown that CFTR is involved in the regulation of exocytosis and insulin secretion in human and mouse beta cells (Edlund et al. 2014), and we have proposed that CFTR is important for insulin granule priming by providing $\mathrm{Cl}^{-}$to the insulin granule via granular $\mathrm{ClC} 3$.

The CftrtmieUR mouse model (van Doorninck et al. 1995, French et al. 1996), here denoted F508del, carries the F508del mutation. The F508del mice are essentially pancreatic sufficient but have a lower body weight and intestinal disease similar to human CF (French et al. 1996, Wilke et al. 2011, Fontes et al. 2015). The F508del mouse model on a FVB background has reduced beta cell mass and increased insulin sensitivity at young age, but developed glucose intolerance with increased age (Fontes et al. 2015). Here, we have investigated intrinsic effects of CFTR in pancreatic islet hormone secretion in young F508del mice on a C57BL/6J background. We hypothesized that the F508del mutation could impair function and/or induce changes in beta cell area. We therefore investigated both changes in beta cell area and the possibility that the F508del beta cells have defective exocytosis and insulin secretion. Finally, we measured islet glucagon and somatostatin secretion. The data presented highlight the important contribution of CFTR in beta cells for functional insulin secretion.

\section{Materials and methods}

\section{Animals and tissues}

The global Cftrm1EuR mouse model (C57BL/6J, F12 backcrosses), heterozygous for the F508del Cftr mutation, was obtained from the Erasmus Medical Center (Rotterdam, Netherlands) (Wilke et al. 2011, Fontes et al. 2015). Heterozygous mice were bred and

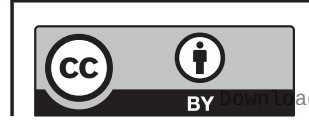

This work is licensed under a Creative Commons Attribution 4.0 Unported License. 
held in isolator cages and fed with standard diet (R36; Lactamin AB, Stockholm, Sweden) and water ad libitum (Ohlsson et al. 2008). Offspring was genotyped by PCR analysis followed by digestion of the PCR product with SspI. The following primer pairs were used: CF-P580: 5'-GGACGCAAAGAAAGGGATAAG; and CF-P581: 5'- CACAACACTGACACAAGTAGC. Female and male wild type (WT) (weight: $23 \pm 0.5 \mathrm{~g}$ ) and homozygous F508del (weight: $20 \pm 0.4 \mathrm{~g}$ ) mice littermates were used in experiments. Littermates aged 7-10 weeks were included in the studies. In one experiment, we used beta cells from C57BL/6J/AKR/CH3 mice. All experiments were performed in accordance with ethical statements and regulations approved by the ethical committees in Stockholm and Lund. Animals were killed by cervical dislocation and islets isolated by collagenase (Sigma-Aldrich) digestion.

\section{Immunocytochemistry}

Islets were handpicked in Hanks buffer (Sigma-Aldrich), dispersed in $\mathrm{Ca}^{2+}$-free buffer, transferred to cell culture media (RPMI-1640; SVA, Uppsala, Sweden) supplemented with $10 \mathrm{mmol} / \mathrm{L}$ glucose, 10v/v FBS (Sigma-Aldrich), $100 \mathrm{IU} / \mathrm{mL}$ penicillin/streptomycin, $2 \mathrm{mmol} / \mathrm{L}$ L-glutamin (both from HyClone, South Logan, UT, USA) and incubated overnight at $37.5^{\circ} \mathrm{C}, 5 \% \mathrm{CO}_{2}$. The cells were fixed in paraformaldehyde, and stained as described (Vikman et al. 2006). Primary antibodies insulin (Millipore) and CFTR (MATG1061; RD Biotech, Besançon, France) (CarvalhoOliveira et al. 2004) were used. Corresponding secondary antibodies (Jackson ImmunoResearch) were detected using confocal laser microscopy (Zeiss instruments) and analyzed using Zen software as described (De Marinis et al. 2010). The INS1-823/13 beta cell line lack CFTR $\left(\mathrm{Ct}_{\mathrm{CFTR}}=\right.$ undetermined, $\quad \mathrm{Ct}_{\mathrm{HPRT}}=23, \quad \mathrm{Ct}_{\mathrm{PPIA}}=18, \quad n=6$ passages) and was used as a negative control for MATG1061 specificity (Supplementary Fig. 1A, see section on supplementary data given at the end of this article).

\section{Immunohistochemistry and morphometry}

Pancreatic sections $(5 \mu \mathrm{m})$ were deparaffinized and hydrated as described elsewhere (Wierup et al. 2004). Sections were incubated with primary antibodies against insulin (9003; EuroDiagnostica, Malmö, Sweden), glucagon (7811; EuroDiagnostica), somatostatin (sc-7819; Santa Cruz Biotechnology) and secondary antibodies (Jackson ImmunoResearch). Immunofluorescence was examined in an epifluorescence microscope (Olympus BX60; Olympus), see example hormone staining in
Supplementary Fig. 2A. For beta cell mass quantification all islets in three different parts of each pancreas (minimum $200 \mu \mathrm{m}$ apart) were assessed in a blinded fashion using NIS-Elements software (NIS-Elements 3.1; Nikon). Total insulin-, glucagon- or somatostatin-stained area and total section area were measured and alpha, beta or delta cell mass was calculated as the ratio between the two areas. Beta cell number per islet was calculated using DAPI as a marker of cell nuclei. All nuclei surrounded by insulin staining were regarded as beta cells. An average of $44 \pm 4$ islets per animal were analyzed $\left(n_{\mathrm{WT}}=21\right.$ pancreatic sections from seven mice, $n_{\mathrm{F} 508 \mathrm{del}}=21$ pancreatic sections from seven mice).

\section{Hormone secretion}

Freshly isolated islets were dispersed, handpicked and stimulated in Krebs buffer supplemented with $1 \mathrm{mmol} / \mathrm{L}$ glucose, $1 \mathrm{mg} / \mathrm{mL}$ albumin for $30 \mathrm{~min}$ followed by $15 \mathrm{~min}$ stimulation in $50 \mathrm{mmol} / \mathrm{L} \mathrm{KCl}$ or $1 \mathrm{~h}$ stimulation in $1 \mathrm{mmol} / \mathrm{L}, 2.8 \mathrm{mmol} / \mathrm{L}$ or $16.7 \mathrm{mmol} / \mathrm{L}$ glucose with or without $10 \mu \mathrm{mol} / \mathrm{L}$ forskolin (Sigma-Aldrich) and/or $50 \mu \mathrm{mol} / \mathrm{L}$ GlyH-101 (Calbiochem) as indicated. After stimulation, islets were dissolved in RIPA buffer $(50 \mathrm{mmol} / \mathrm{L}$ TRIS- $\mathrm{HCl}, 150 \mathrm{mmol} / \mathrm{L} \mathrm{NaCl}, 0.5 \mathrm{mmol} / \mathrm{L} \mathrm{NaDeoxycholate,}$ $2 \mathrm{mmol} / \mathrm{L}$ EDTA, $50 \mathrm{mmol} / \mathrm{L} \mathrm{NaF}, 1 \mathrm{v} / \mathrm{v}$ Triton-X, $0.1 \mathrm{v} / \mathrm{v}$ SDS (all from Merck) and sonicated. Supernatant and dissolved islets were analyzed with RIA using antibodies to detect insulin (RI-13K), C-peptide, glucagon (GL-32K; all three from Millipore) and somatostatin (Mercodia $\mathrm{AB}$, Malmö, Sweden). Secreted proinsulin was analyzed with rat/mouse proinsulin ELISA (10-1232-01, Mercodia AB). Secretion experiments were performed independently on four occasions using islets pooled from 3 to 5 animals of each genotype and 3-5 technical replicates with 12 islets per replicate for each condition $(n=4)$. Secretion experiment in high $\mathrm{K}^{+}(50 \mathrm{mM})$ were performed on islets from individual male mice ( $N_{\mathrm{WT}}=5$ mice, $N_{\mathrm{F} 508 \text { del }}=5$ mice).

\section{Patch-clamp measurements}

An EPC-10 amplifier and Patchmaster software (HEKA Elektronik, Lambrecht(Pfalz), Germany) were used to evoke and record whole-cell currents and changes in membrane capacitance in dispersed beta cells as described in Eliasson et al. (2003). Mouse beta cells were distinguished from alpha and delta cells by the electrophysiological properties of the $\mathrm{Na}^{+}$current inactivation (Gopel et al. 2000). The extracellular solution contained the following (in mmol/L): $118 \mathrm{NaCl}, 20 \mathrm{TEA}-\mathrm{Cl}, 5.6 \mathrm{KCl}, 2.6 \mathrm{CaCl}_{2}$, 
$1.2 \mathrm{MgCl}_{2}, 5$ HEPES and 5 Glucose ( $\left.\mathrm{pH} 7.4 \mathrm{NaOH}\right)$. The intracellular solution contained the following (in mmol/L): $125 \mathrm{CsOH}, 125$ L-glutamic acid, $10 \mathrm{CsCl}, 10$ $\mathrm{NaCl}, 1 \mathrm{MgCl}_{2}, 5$ HEPES, $3 \mathrm{Mg}$-ATP, 0.05 EGTA and 0.1 cAMP (pH 7.15 CsOH). All chemicals are from Merck.

\section{Transmission electron microscopy}

Islets were fixed in $2.5 \%$ glutaraldehyde and treated with osmium (both from Sigma-Aldrich) as described in Andersson et al. (2011). Analysis to estimate total number of granules as volume density $N_{\mathrm{v}}$ (granules/ $/ \mathrm{mm}^{3}$ ) and number of docked granules as surface density $N_{\mathrm{s}}$ (granules/ $\mu \mathrm{m}^{2}$ ) were performed using the diameter of the insulin granules $\left(D_{\mathrm{WT}}=272 \pm 2.8 \mathrm{~nm}\right.$ and $\left.\mathrm{D}_{\mathrm{F} 508 \mathrm{del}}=272 \pm 3.3 \mathrm{~nm}\right)$ and an in-house program in MATLAB. A granule was considered docked if the center of the granule was within $150 \mathrm{~nm}(\sim \mathrm{D} / 2)$ from the plasma membrane (Olofsson et al. 2002).

\section{Intragranular pH measurements}

Dispersed single cells from C57BL/6J/AKR/CH3 mice were plated onto poly-D-lysine-coated glass bottom culture dishes and incubated overnight. Before experiments, cells were incubated with $1 \mu \mathrm{M}$ LysoSensor green DND-189 (L-7535; Invitrogen; Thermo Fisher) in Krebs buffer for $40 \mathrm{~min}$. During experiments, cells were perfused at a flow rate of $1 \mathrm{~mL} / \mathrm{min}$ at $32^{\circ} \mathrm{C}$ with Krebs buffer supplemented with $2.8 \mathrm{mM}$ or $16.7 \mathrm{mM}$ glucose and with $10 \mu \mathrm{M}$ forskolin in the presence or absence of $25 \mu \mathrm{M}$ GlyH-101. Confocal laser microscopy (Zeiss instruments) was used to measure DND-189 fluorescence (excitation $443 \mathrm{~nm}$; emission $505 \mathrm{~nm}$ ) and data was analyzed using Zen software. To subtract rundown, fluorescence was normalized to traces measured at $2.8 \mathrm{mM}$ glucose alone.

\section{In vivo measurements}

Animals were fasted overnight and $1 \mathrm{mg} / \mathrm{g}$ glucose in PBS was injected intra-peritoneally (maximum $200 \mu \mathrm{L} /$ animal) and blood glucose levels were measured. Venous blood was collected from tail-vein of unanesthetized animals. Blood glucose levels were measured using Glucometer Elite Strips (Bayer) and serum insulin and glucagon levels were analyzed with ELISA (Insulin: 10-1247-01, Glucagon: 10-1281-01; Mercodia AB). Rate of glucose clearance was estimated by subtraction of the blood glucose value at each time point with the previous blood glucose value divided by the time.

\section{Statistical analysis}

Data are presented as mean \pm S.E.M. of number of animals $(N)$ or number of experiments/cells $(n)$. Students $t$-test and ANOVA were used to calculate statistical significance and a $P<0.05$ value was considered statistically significant.

\section{Results}

\section{F508del islets have reduced beta cell mass}

We studied CFTR protein expression in dispersed F508del and WT beta cells using confocal immunocytochemistry. CFTR was detected using the MATG-1061 monoclonal antibody; shown to recognize not only CFTR but also F508del-CFTR (Carvalho-Oliveira et al. 2004) (Fig. 1A). Plasma membrane expression of CFTR in beta cells from F508del mice was lower than in WT mice (Fig. 1B), which is in accordance with reduced surface expression of F508del-CFTR in other tissues (French et al. 1996). The 2D surface area size of individual beta cells was $20 \%$ smaller in F508del compared to WT beta cells (Fig. 1C).

We next calculated beta cell area from pancreas sections immunostained for insulin (Supplementary Fig. 2A), since a previous observation in the F508del mice suggests that the main reason for reduced insulin secretion in these mice is reduced beta cell mass (Fontes et al. 2015). Our calculations confirmed a reduced beta cell area in F508del mice (Fig. 1D). However, when we counted the number of nuclei as a measurement of number of beta cells within the insulin stained area there was no difference between F508del and WT mice (Fig. 1E). The pancreas weight was similar between the animals (Supplementary Fig. 2B). Alpha or delta cell area was not different between F508del mice and WT mice (Fig. 1F and G, Supplementary Fig. 2A).

\section{F508del beta cells secrete more proinsulin and less C-peptide}

We asked the question if the Cftr mutation affects beta cell function and measured insulin secretion from isolated islets. We measured insulin release after $1 \mathrm{~h}$ incubation in the non-stimulatory (basal) glucose concentration $1 \mathrm{mmol} / \mathrm{L}$ and the stimulatory glucose concentration $16.7 \mathrm{mmol} / \mathrm{L}$, respectively. CFTR was activated using the cAMP-increasing agent forskolin and CFTR function was blocked by the CFTR-antagonist GlyH-101. We found reduced basal insulin secretion in F508del (Fig. 2A).

This work is licensed under a Creative Commons Attribution 4.0 Unported License. 
A WT

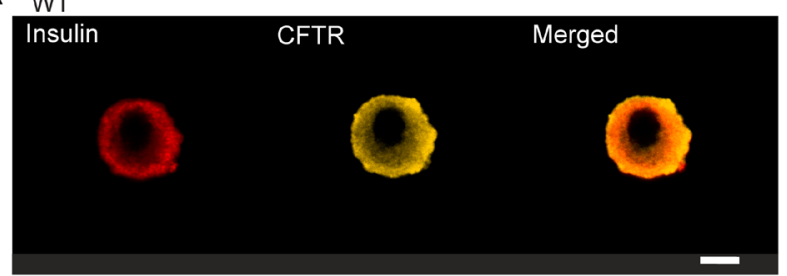

F508del

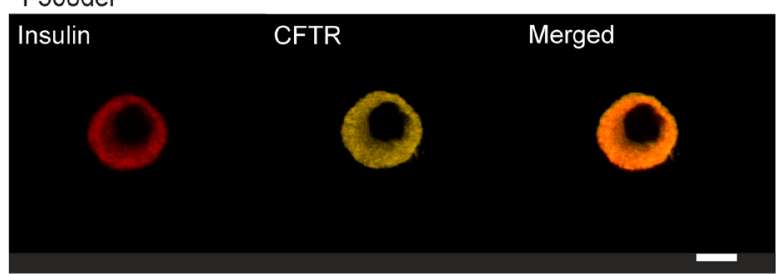

D

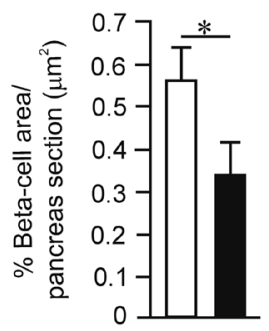

E

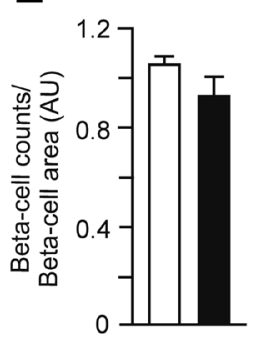

$\mathrm{F}$

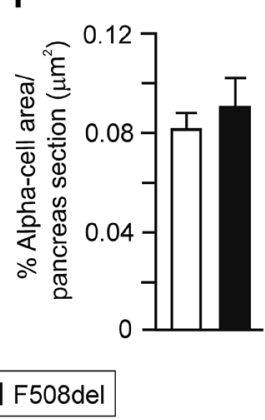

B
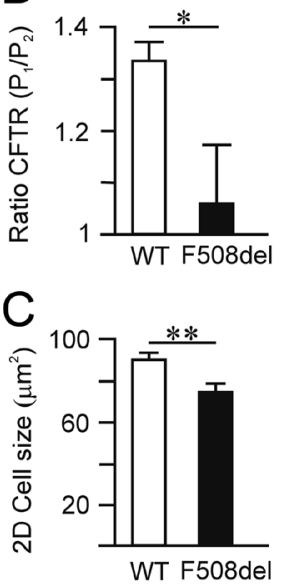

G

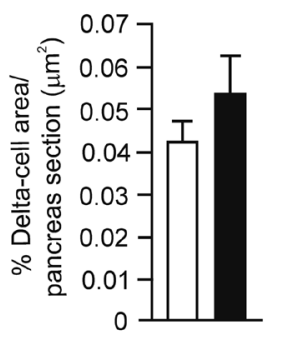

\section{Figure 1}

Morphological investigation of WT and F508del islets and beta cells. (A) Representative image of CFTR (yellow) and insulin (red) localization using confocal immunocytochemistry in fixed single beta cells from a WT and a F508del beta cell. Scale bar $5 \mu \mathrm{m}$. (B) The ratio of CFTR protein expression in the plasma membrane region $\left(P_{1}\right)$ compared to the cytosol $\left(\mathrm{P}_{2}\right)$ in WT $(n=14)$ and F508del $(n=11)$ in insulin positive cells as in (A). (C) Single 2D area cell size of insulin positive cells measured on confocal images using Zen software. (D) Beta cell mass in WT and F508del islets using insulin immunohistochemistry. (E) Number of beta cells within the insulin stained area in the histology sections in (D). (F) Alpha cell mass and (G) delta cell mass as in (D). Data are presented as mean \pm S.E.M., white bar: WT and black bar: F508del, $* P<0.05, * * P<0.01$. A full color version of this figure is available at https://doi. org/10.1530/JOE-18-0570.
As expected, addition of forskolin did not affect basal insulin secretion in the WT, whereas it slightly enhanced basal release in the F508del islets.

In accordance with our previously published data (Edlund et al. 2014), inhibition of CFTR by GlyH-101 reduced glucose-stimulated insulin secretion in the presence of forskolin in WT islets by $\sim 40 \%$ (Fig. 2B). We have previously demonstrated the specificity of GlyH-101 for CFTR (Edlund et al. 2017). The specificity was further confirmed using INS1-823/13 cells, which do not express CFTR (Supplementary Fig. 1A). GlyH-101 did not affect glucose and IBMX-stimulated insulin secretion in INS1-823/13 cells (Supplementary Fig. 1B).

Glucose-stimulated insulin secretion did not differ between F508del islets and WT islets (Fig. 2B). Moreover, forskolin elevated glucose-stimulated insulin secretion to a larger extent in the F508del islets (Fig. 2B). We believe these surprising results are partly due to reduced insulin content in F508del islets compared to WT islets (Supplementary Fig. 3A), and partly due to the insulin RIA which does not discriminate between insulin and proinsulin. We therefore measured the secretion of proinsulin and C-peptide separately from the same samples. Proinsulin secretion from F508del islets was markedly increased during cAMP-stimulation (Fig. 2C, Supplementary Fig. 3D). Moreover, GlyH-101 increased proinsulin secretion from WT islets while having no further effect on F508del islets (Fig. 2C). In line with that observation, C-peptide secretion was decreased in F508del islets (Fig. 2D, Supplementary Fig. 3E).

\section{F508del beta cells have defective exocytosis of insulin granules}

We have previously suggested that CFTR regulates exocytosis in beta cells (Edlund et al. 2014). We therefore measured depolarization-induced insulin secretion after incubation in $50 \mathrm{mmol} / \mathrm{L} \mathrm{K}^{+}$during $15 \mathrm{~min}$ to investigate insulin secretion downstream of beta cell depolarization. Depolarization-induced insulin secretion was reduced by $\sim 30 \%$ in F508del islets (Fig. 2E) compared to WT. In the simultaneous presence of forskolin the reduction was nearly $\sim 40 \%$ (Fig. $2 \mathrm{E}$ ). During this short stimulation in the absence of glucose there was no difference in proinsulin secretion between F508del and WT mouse islets (Fig. 2F).

To examine the effect of CFTR deficiency on exocytosis in detail we measured exocytosis in single F508del and 
A 0

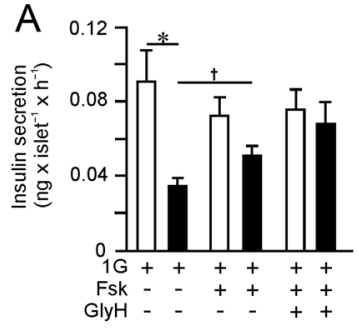

C

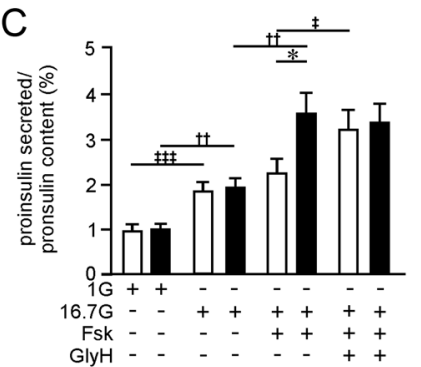

$\mathrm{E}$

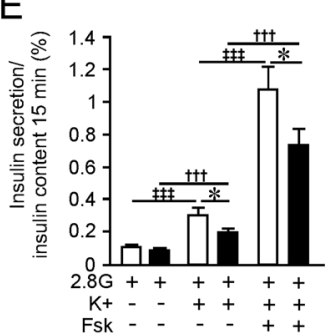

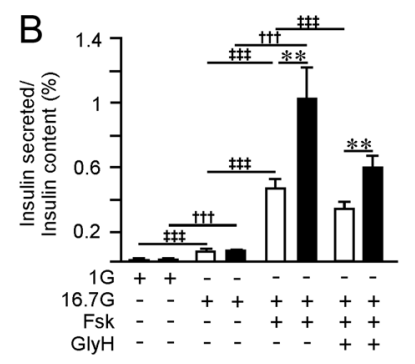

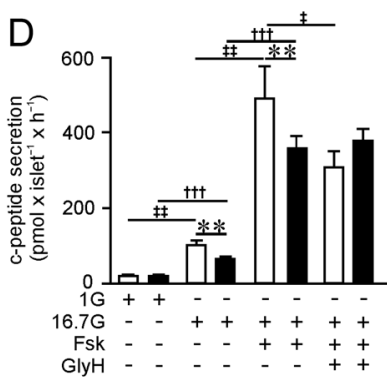

$\mathrm{F}$

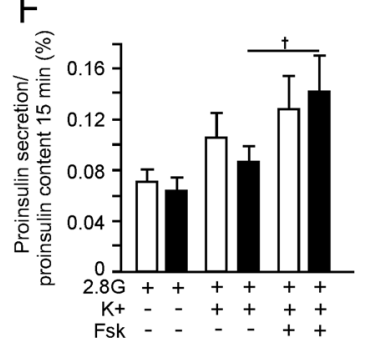

WT $\square$ F08del

\section{Figure 2}

Insulin, proinsulin and c-peptide secretion from islets isolated from F508del and WT mice. (A) Insulin secretion at $1 \mathrm{mmol} / \mathrm{L}$ glucose (1 G) and CAMP-amplified using $10 \mu \mathrm{mol} / \mathrm{L}$ forskolin (Fsk). CFTR was inhibited using $50 \mu \mathrm{mol} / \mathrm{L} \mathrm{GlyH}-101(\mathrm{GlyH})$ in WT and F508del islets $\left(n_{\mathrm{WT}}=4, n_{\mathrm{F} 508 \mathrm{del}}=4\right)$. (B) Insulin secretion at $16.7 \mathrm{mmol} / \mathrm{L}$ glucose (16.7 G) and CAMP-amplified using forskolin in WT and F508del islets expressed per insulin content. CFTR was inhibited using $50 \mu \mathrm{mol} / \mathrm{L} \mathrm{GlyH}-101\left(\mathrm{GlyH}, n_{\mathrm{WT}}=4, n_{\text {F508del }}=4\right)$. (C) Proinsulin secretion per proinsulin content and (D) C-peptide secretion measured in the same sample as in (B). (E) Depolarization-induced insulin secretion per insulin content in $2.8 \mathrm{mmol} / \mathrm{L}$ glucose $(2.8 \mathrm{G})$ and $50 \mathrm{mmol} / \mathrm{L}$ $\mathrm{KCl}\left(\mathrm{K}^{+}\right)$with or without $10 \mu \mathrm{M}$ forskolin (Fsk) in islets from separate mice (not pooled, $N_{\mathrm{WT}}=5, N_{\mathrm{F} 508 \mathrm{del}}=5$ ). (F) Proinsulin secretion per proinsulin content measured in the same samples as in (A). Data are presented as mean \pm S.E.M., white bar: WT and black bar: F508del, $* P<0.05, * * P<0.01$ WT vs F508del, $\neq P<0.05,{ }^{\ddagger} P<0.01,{ }^{\ddagger \ddagger} P<0.001$ within WT as compared to another condition, ${ }^{\dagger} P<0.05,{ }^{\dagger \dagger} P<0.01,{ }^{t+t} P<0.001$ within F508del as compared to another condition.

WT beta cells using standard whole-cell capacitance measurements. The increase in membrane capacitance, elicited by a train of ten $500-\mathrm{ms}$ depolarizations from $-70 \mathrm{mV}$ to $0 \mathrm{mV}$, was significantly reduced in F508del beta cells compared to WT beta cells (Fig. 3A, B and C). The increase in membrane capacitance evoked by the first two depolarizations in the train, reflecting ATP-independent exocytosis of primed and pre-docked granules (Eliasson et al. 1997), was reduced by $\sim 50 \%$

(Fig. 3C). ATP-dependent exocytosis, the latter eight depolarizations, was less affected (Fig. 3C). The reduced exocytosis was not due to a reduced influx of $\mathrm{Ca}^{2+}$ (Supplementary Fig. 4).

Docking of granules is important for functional exocytosis and we wanted to confirm that mutations in Cftr reduce the docked pool of granules. To this end, transmission electron microscopy was employed (Fig. 3D, $\mathrm{E}, \mathrm{F}$ and $\mathrm{G})$. In line with our previous findings in NMRI mouse and human beta cells treated with CFTR inhibitors (Edlund et al. 2014), F508del beta cells had a reduced surface density $\left(\mathrm{N}_{\mathrm{s}}\right.$ ) of granules (Fig. 3F) while the total volume density $\left(\mathrm{N}_{\mathrm{v}}\right)$ was similar between F508del and WT beta cells (Fig. 3G).

Cleavage of proinsulin to insulin and C-peptide and the process of insulin granular priming require low intragranular $\mathrm{pH}$. We therefore measured granular $\mathrm{pH}$ in mouse beta cells using the fluorescent dye DND-189 that specifically can be used to measure $\mathrm{pH}$ of acidic organelles (Fig. $3 \mathrm{H}$ and I). We observed a reduction in $\mathrm{pH}$ after stimulation with $16.7 \mathrm{mM}$ glucose in presence of forskolin (in 15/32 cells) in agreement with previous measurements (Eliasson et al. 2003). The reduction was reverted in presence of the CFTR-inhibitor GlyH-101.

\section{Forskolin-induced glucagon secretion in the F508del mouse is impaired}

Recent data show increased glucagon secretion after CFTR inhibition in both human and mouse islets, suggesting an intrinsic function of CFTR also in alpha cells (Edlund et al. 2017, Huang et al. 2017). We asked if the CFTR mutation would have the same effect and investigated glucagon secretion properties in islets from the F508del mice. F508del and WT islets were subjected to $1 \mathrm{~h}$-incubation in $1 \mathrm{mmol} / \mathrm{L}$ glucose to maximally stimulate glucagon secretion. Under this condition, F508del islets displayed higher glucagon secretion compared to WT islets (Fig. 4A). In agreement with previous findings, forskolin caused a fourfold amplification of glucagon secretion in WT islets (Fig. 4A). Interestingly, the already high level of glucagon secretion observed in F508del islets at $1 \mathrm{mmol} / \mathrm{L}$ glucose alone was not further enhanced by forskolin. At $16.7 \mathrm{mmol} / \mathrm{L}$ glucose, glucagon secretion was elevated in F508del islets as compared to WT islets. Glucagon secretion from WT islets was (as expected) reduced (Fig. 4B), whereas there was no significant difference in glucagon secretion from F508del islets as compared to $1 \mathrm{mmol} / \mathrm{L}$ glucose.

We have suggested that CFTR regulates electrical activity in the alpha cell with a small direct effect 
A

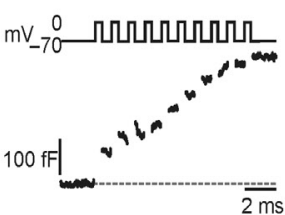

B

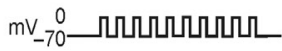
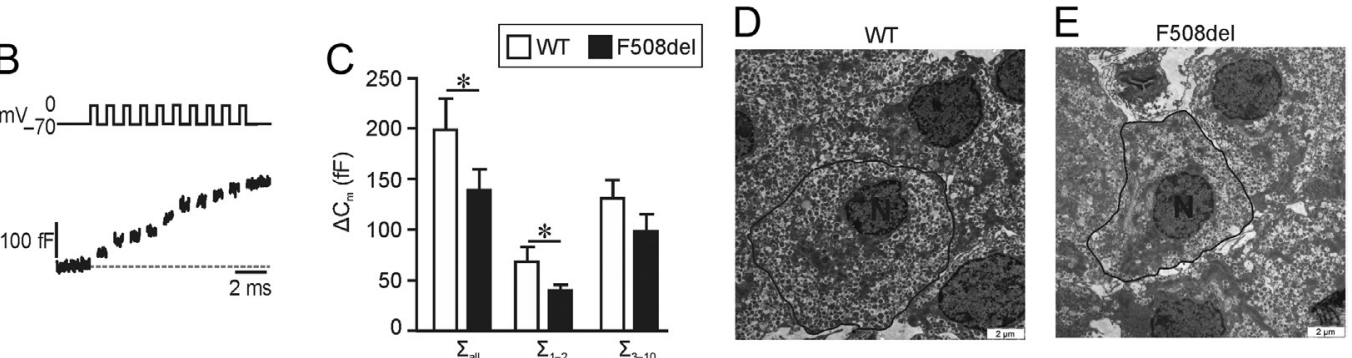

F

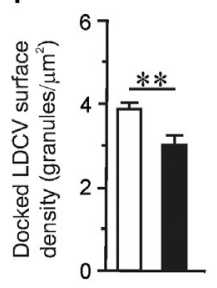

G

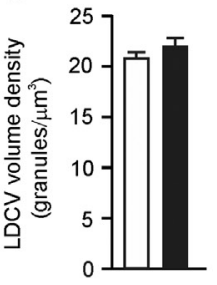

$\mathrm{H}$
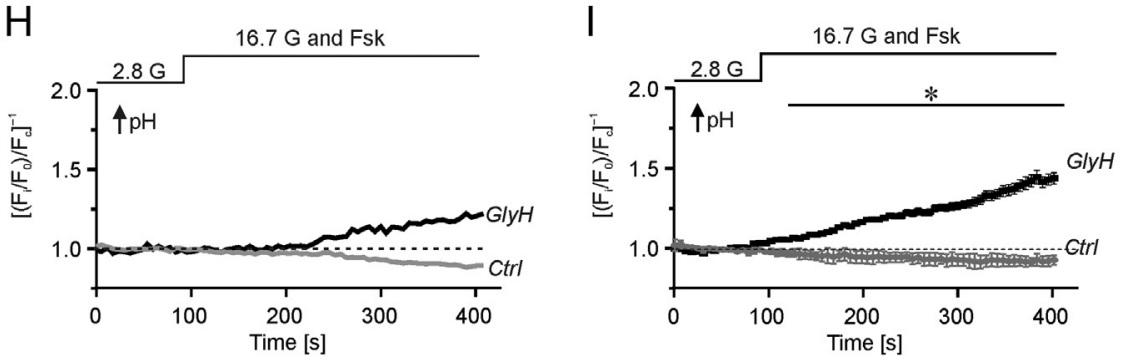

Figure 3

Exocytosis of insulin containing granules in WT and F508del beta cells. (A) Membrane capacitance increase during a train of ten 500-ms depolarizations from $-70 \mathrm{mV}$ to $0 \mathrm{mV}$ in a single beta cell from WT mice. (B) As in (A) but on a single F508del beta cell. (C) Summary of the total increase in membrane capacitance from all experiments $\left(\Sigma_{\text {all, }}, n_{\mathrm{WT}}=16, n_{\mathrm{F} 508 \mathrm{del}}=16\right)$ as in $(\mathrm{A})$ and $(\mathrm{B})$, during the first two depolarizations $\left(\Sigma_{1-2}\right)$ and during the latter eight depolarizations $\left(\Sigma_{3-8}\right)$. (D) A transmission electron microscopic micrograph of a single beta cell in a WT islet. The plasma membrane is indicated with a solid black line and $\mathrm{N}=$ nucleus. (E) As in (D) but in an F508del islet. (F) An estimation of the number of large dense core vesicles (LDCV) docked at the plasma membrane measured as surface density $\left(N_{S}\right)\left(n_{W T}=28\right.$ beta cells from two mice, $n_{F 508 d e l}=33$ beta cells from two mice). (G) An estimation of the total amount of vesicles measured as LDCV volume density $\left(N_{\mathrm{v}}\right)\left(n_{\mathrm{WT}}=28\right.$ beta cells from two mice, $n_{\mathrm{F} 508 \mathrm{del}}=33$ beta cells from two mice). Data are presented as mean \pm S.E.M., white bar: WT and black bar: F508del, ${ }^{*} P<0.05,{ }^{*} * P<0.01$ WT vs F508del, ${ }^{\prime \neq \ddagger} P<0.001$ within WT compared to another condition, ${ }^{\dagger} P<0.05$, ${ }_{t+t} P<0.001$ within F508del as compared to another condition. (H) Typical experiments measuring $\mathrm{pH}$ as the fluorescence of the probe DND-189 in the absence and presence of GlyH-101(GlyH) as indicated. DND-189 fluorescence increase with reduced pH. For clarity we present the inverse fluorescence $\left(\left[\left(F_{i} / F_{0}\right) / F_{c}\right]^{-1}\right)$ so that traces goes below baseline for reduced $\mathrm{pH}$ and increases when the $\mathrm{pH}$ increases as indicated. Lowering of granular $\mathrm{pH}$ was achieved by addition of $16.7 \mathrm{mM}$ glucose $(\mathrm{G})$ in presence of $10 \mu \mathrm{M}$ forskolin (Fsk). The traces were normalized to recordings performed in presence of $2.8 \mathrm{mM}$ glucose alone. (I) Summary of results performed as in (H). Data are presented as S.E.M. \pm S.D. $\left(n_{\text {Crrl }}=15\right.$ cells, $n_{\text {GlyH }}=54$ cells from N=3 mice).

on exocytosis in rodent (Edlund et al. 2017). Here, depolarization-induced glucagon secretion was increased twofold in F508del islets as compared to WT islets when experiments where performed in the presence of forskolin (Fig. 4C). The dysregulated glucagon secretion in F508del islets was not explained by a difference in glucagon content (Fig. 4D).

\section{Impaired somatostatin secretion in the F508del mouse}

We measured somatostatin secretion and found that it was elevated in F508del islets compared to WT islets under all glucose conditions (Fig. 4E and F). Normally, cAMPincreasing agents amplify somatostatin secretion during glucose-stimulated conditions (Gerber et al. 1981, de Heer et al. 2008), which was also the case in the WT islets (Fig. 4F). Surprisingly, forskolin reduced somatostatin secretion in F508del islets during glucose-stimulated conditions (Fig. 4F), but increased somatostatin secretion from islets stimulated in low glucose (Fig. 4E).

\section{The F508del mouse has improved glucose tolerance but reduced glucose clearance}

Finally, we investigated glucose homeostasis in the F508del mouse in vivo. Fasting blood glucose levels were lower in F508del mice as compared to WT mice (Fig. 5A). Serum insulin was similar in WT and F508del mice (Fig. 5B), while average serum glucagon was three times higher in the F508del mice (Fig. 5C). F508del mice subjected to an intraperitoneal glucose tolerance test (IPGTT) for 120 min demonstrated overall lower increases in blood glucose levels than the WT mice, when calculated as the incremental area under the curve (iAUC) during the sampling period (Fig. 5D and E). In the WT mice, an initial glucose peak (after $\sim 10 \mathrm{~min}$ ) was followed by a continuous and significant lowering of blood glucose levels reaching the levels of the fasting state after $120 \mathrm{~min}$, whereas in the F508del mice blood glucose remained similarly elevated during the first $30 \mathrm{~min}$ of the glucose challenge (Fig. 5D). We used the data measured during the IPGTT to calculate glucose clearance (Fig. 5F). Glucose clearance was delayed

This work is licensed under a Creative Commons Attribution 4.0 Unported License. 

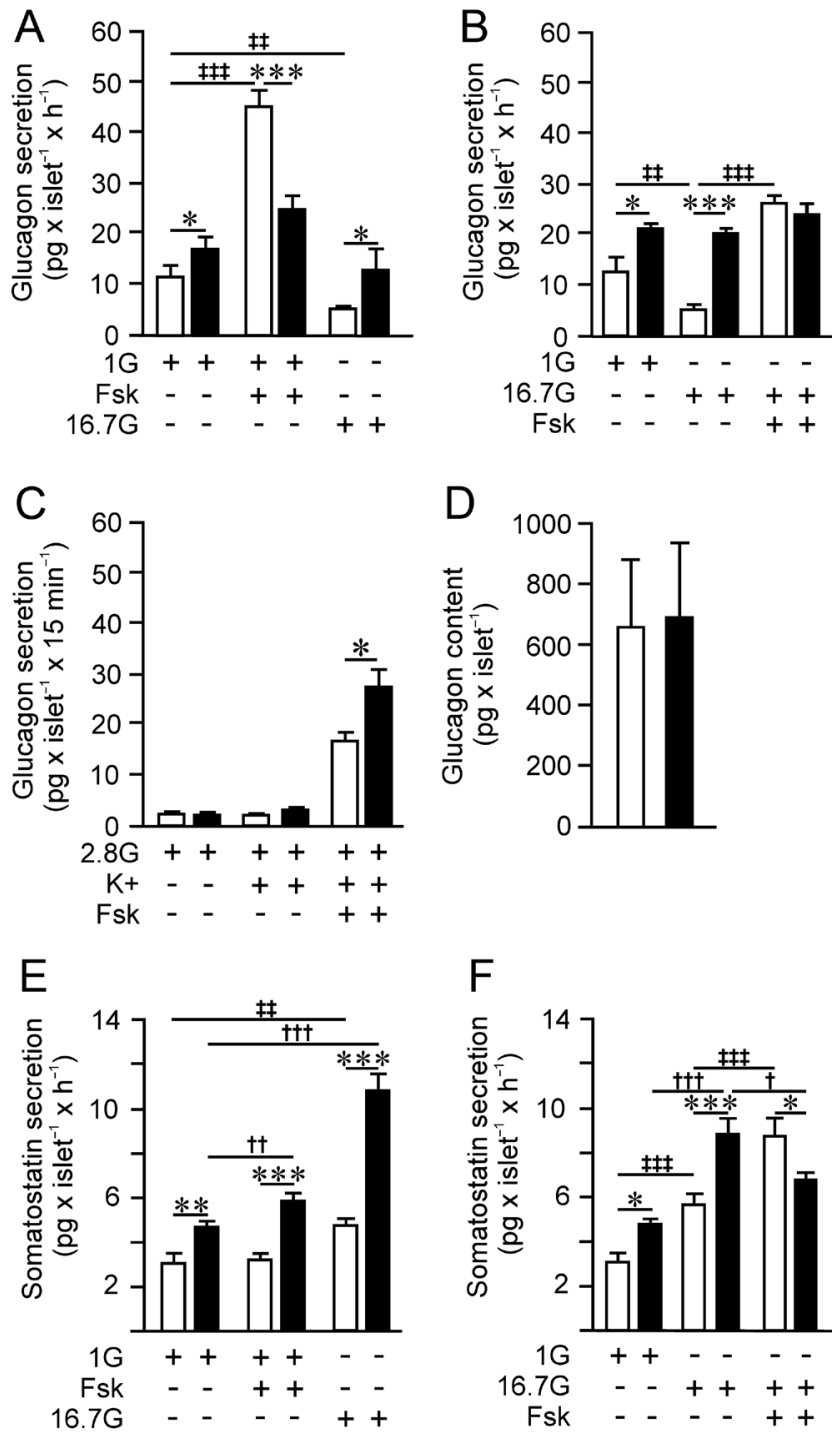

$\square$ WT $\square$ F508del

\section{Figure 4}

Glucagon and somatostatin secretion from isolated F508del and WT islets. (A) Glucagon secretion at $1 \mathrm{mmol} / \mathrm{L}$ glucose (1G) and CAMPamplified using $10 \mu \mathrm{mol} / \mathrm{L}$ forskolin (Fsk) in WT islets and F508del islets $\left(n_{\mathrm{WT}}=4, n_{\text {F508del }}=4\right)$. (B) Glucagon secretion at $16.7 \mathrm{mmol} / \mathrm{L}$ glucose (16.7G) amplified using forskolin in WT and F508del islets $\left(n_{\mathrm{WT}}=4\right.$, $\left.n_{\text {F508del }}=4\right)$. (C) Depolarization-induced glucagon secretion in $2.8 \mathrm{mmol} / \mathrm{L}$ glucose $(2.8 \mathrm{G})$ and $50 \mathrm{mmol} / \mathrm{L} \mathrm{KCl}\left(\mathrm{K}^{+}\right)$with or without $10 \mu \mathrm{mol} / \mathrm{L}$ forskolin in islets from separate mice (not pooled, $N_{W T}=5, N_{\text {f508del }}=5$ ). (D) Glucagon content in islets from (A) and (B). (E) Somatostatin secretion measured at $1 \mathrm{mmol} / \mathrm{L}$ glucose and amplified using forskolin in WT islets and F508del islets $\left(n_{\mathrm{WT}}=4, n_{\mathrm{F} 508 \mathrm{del}}=4\right)$. (F) Somatostatin secretion in $16.7 \mathrm{mmol} / \mathrm{L}$ glucose and in presence or absence of forskolin in WT and F508del islets $\left(n_{\mathrm{WT}}=4, n_{\mathrm{F} 508 \mathrm{del}}=4\right)$. Data are presented as mean \pm S.E.M., white bar WT and black bar F508del $* P<0.05, * \star p<0.01, * \star * P<0.001$ WT vs F508del, ${ }^{\ddagger} P<0.01,{ }^{\ddagger \ddagger} P<0.001$ within WT as compared to another condition, ${ }^{\dagger} P<0.05,{ }^{\dagger \dagger} P<0.01,{ }^{+\dagger} P<0.001$ within F508del as compared to another condition. https://joe.bioscientifica.com https://doi.org/10.1530/JOE-18-0570 (c) 2019 The authors Published by Bioscientifica Ltd. Printed in Great Britain in F508del mice and blood glucose did not return to the fasted state in the F508del animals within the sampling period (Fig. 5D).

\section{Discussion}

We show that exocytosis is defective in F508del beta cells together with reduced number of docked insulin granules at the plasma membrane. This is in agreement with our previously published data (Edlund et al. 2014), which showed involvement of CFTR in human insulin secretion and beta cell exocytosis. Moreover, we present evidence suggesting that F508del mice have a defective processing and maturation of insulin, manifested as increased proinsulin secretion and decreased C-peptide secretion in forskolin- and glucose-stimulated conditions. Our data suggest that the F508del mutation results in an intrinsic beta cell defect.

During a glucose challenge, the beta cell release insulin in two phases. One rapid first-phase lasting 10-15 min followed by a slower sustained second-phase lasting for hours. Patients with CF have reduced firstphase insulin secretion (Moran et al. 1991, Bellin et al. 2013). During the IPGTT F508del mice had a lower glucose increase in response to the glucose challenge compared to WT (Fig. 5D). The F508del is a global transgenic mouse with CFTR affected in all cells of the body. The mouse most likely have adapted to its genotype, for example a leaner body (WT $23 \pm 0.5 \mathrm{~g} N_{\mathrm{WT}}=45$ vs F508del $20 \pm 0.4 \mathrm{~g}$ $N_{\text {F508del }}=48, P<0.001$; Supplementary Fig. $2 \mathrm{~B}$ ) and lower fasting glucose levels compared to WT (Fig. 5A). In the IPGTT, the glucose curve is shifted below the WT. Despite that, the shape of the curve indicates that F508del have a defective glucose handling. It takes $30 \mathrm{~min}$ before glucose elimination starts, which may reflect a reduced first-phase insulin secretion. But as we have not measured insulin secretion in vivo we cannot exclude that the defective glucose handling is due to peripheral insulin resistance. However, in vivo measurements in the Cftrtm1Eur/F508del mice on FVB background indicate that these mice have increased insulin sensitivity at 11 week and increased insulin resistance at week 24 (Fontes et al. 2015) favoring that the defective glucose handling is coupled to impaired insulin secretion in our study (with 8-weekold mice). Indeed, we observe reduced insulin secretion in vitro in F508del mice. It is possible that the defective insulin secretion observed when studying F508del islets on $\mathrm{C} 57 \mathrm{BL} / 6 \mathrm{~J}$ background in vitro are not detected in vivo due to the leaner phenotype causing increased peripheral insulin sensitivity (Backhed et al. 2004, Fontes et al. 2015).

This work is licensed under a Creative Commons Attribution 4.0 Unported License. 

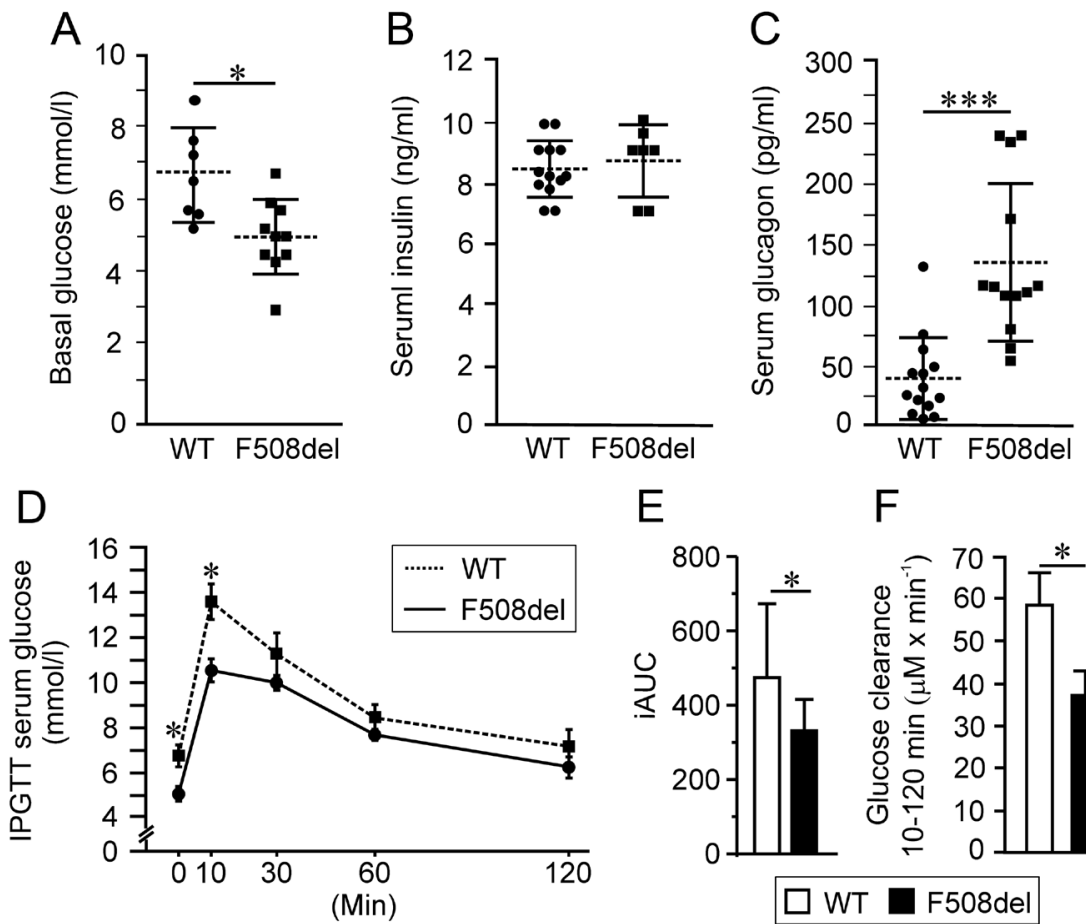

$\mathrm{E}$

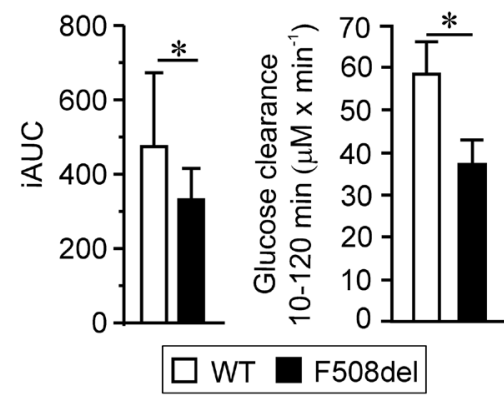

Figure 5

In vivo insulin, glucagon and glucose measurements in WT and F508del mice. (A) Fasting glucose level in WT and F508del mice $\left(n_{\mathrm{WT}}=10, n_{\mathrm{F} 508 \mathrm{del}}=7\right)$. (B) Serum insulin $\left(n_{\mathrm{WT}}=13\right.$, $\left.n_{\text {F508del }}=7\right)$ and $(C)$ serum glucagon $\left(n_{\mathrm{WT}}=14\right.$, $\left.n_{\mathrm{F} 508 \mathrm{del}}=13\right)$. (D) Glucose response to IPGTT $\left(n_{\mathrm{WT}}=10, n_{\mathrm{F} 508 \mathrm{del}}=7\right)$. (E) Glucose response during IPGTT measured as the incremental AUC (iAUC). (F) Glucose clearance ( $\mu \mathrm{M} / \mathrm{min})$ during IPGTT measured as the linear reduction in blood glucose level from the glucose peak at $10 \mathrm{~min}$ to the final time point at $120 \mathrm{~min}$. Data are presented as mean \pm S.E.M., WT (black filled dots, white bar, dashed line) and F508del (black filled squares, black bar, solid line); $* P<0.05$, $\star \star P<0.01$ and $* \star * P<0.001$.
In vitro, first-phase insulin secretion is suggested to be manifested by the release of primed granules measured after (1) a short (15 min) depolarizing stimulation of the islets using, for example, high concentration of $\mathrm{K}^{+}$or (2) stimulation of depolarization-induced exocytosis of already primed granules using single-cell patch-clamp measurements (Daniel et al. 1999, Olofsson et al. 2002). Here, we used these two techniques and found that depolarization-induced insulin secretion (Fig. 2E) and rapid exocytosis of docked insulin granules were reduced in F508del islets (Fig. 3A, B and C), suggesting defective first-phase insulin secretion in F508del beta cells. The electron microscopy analysis further confirmed a role for CFTR in insulin granule docking (Fig. 3F). It has been suggested that CFTR regulates the $\mathrm{K}_{\mathrm{ATP}}$ channel at least in ferret islets (Sun et al. 2017). Stimulation of the islets with high $\mathrm{K}^{+}$or measurements of exocytosis using patch-clamp bypass the $\mathrm{K}_{\text {ATP }}$ channel, that is why the results presented here cannot be explained by direct involvement of the $\mathrm{K}_{\text {ATP }}$ channel.

The functional importance of CFTR in beta cells has been questioned (Sun et al. 2017, Hart et al. 2018). Single cell transcriptome analysis of human islet cells show that CFTR is expressed in a subset of alpha and beta cells (Blodgett et al. 2015, Baron et al. 2016, Segerstolpe et al. 2016). The single cell transcriptome analyses have revealed a transcriptome heterogeneity in the beta cell population suggesting that there are different pools of beta cells (Baron et al. 2016). Indeed, the presence of specific pacemaker beta cells dictating the beta cell response have been suggested (Johnston et al. 2016). Hence, in light of the transcriptomic analysis and our recent human data (Edlund et al. 2014), an important intrinsic functional role of CFTR in islet cells, despite relatively low expression, cannot be excluded. Our data from young F508del mice support an intrinsic beta cell defect by the observed defects in docking of granules and reduced exocytosis.

The conversion of proinsulin to insulin and C-peptide requires a low $\mathrm{pH}$. $\mathrm{H}^{+}$are vital for optimal conversion (Davidson et al. 1988), and $\mathrm{Cl}^{-}$counteract the electrostatic gradient across the granule membrane formed by the entry of $\mathrm{H}^{+}$(Barg et al. 2001). We found that both F508del beta cells and inhibition of CFTR in WT islets caused an increase in secreted proinsulin (Fig. 2C) during $1 \mathrm{~h}$ glucose stimulation, whereas the secretion of proinsulin was not as affected during short depolarization-induced beta cell secretion, where instead the exocytotic response was clearly reduced (Fig. 2E and 3A, B and C). Moreover, we could measure reduced $\mathrm{pH}$ in beta cells when priming was stimulated with glucose and cAMP: an effect that was counteracted with GlyH-101 (Fig. 3H and I). Thus, these data indicate that CFTR is involved in the pH-dependent acidification needed for proinsulin conversion and priming of granules. Taken together these results suggests

This work is licensed under a Creative Commons Attribution 4.0 Unported License. 
that dysfunctional CFTR impair insulin secretion through (1) impaired docking and priming of insulin granules leading to reduced exocytosis measured by short time beta cell stimulation and (2) defective insulin maturation resulting in reduced release of mature insulin and increased release of proinsulin in the later phase of insulin secretion. It is tempting to speculate that the defective exocytosis stresses the F508del beta cell and contributes to the progressive failure seen with age reported by Fontes et al. (2015). Moreover, CF patients have been reported to have a skewed proinsulin to insulin ratio (Hartling et al. 1988, Hamdi et al. 1993, Sheikh et al. 2017, Nyirjesy et al . 2018), which has also been shown in F508del pig (Uc et al. 2015). It can be argued that loss of beta cell mass or endoplasmatic reticulum stress due to misprocessed F508del-CFTR increase proinsulin secretion (Seaquist et al. 1996). However, we found that the reduced beta cell area in 7-9-week-old F508del mice was mainly due to reduced cell size and not number. Moreover, proinsulin content was unchanged between F508del and WT islets (Supplementary Fig. 3B), suggesting defects mainly in the last step of insulin maturation.

In addition to the reduced beta cell function, loss of beta cell mass is implicated in CFRD where the continuous inflammation of the exocrine pancreas has been proposed to eventually affect the islets (Gibson-Corley et al. 2015). A previously reported study shows that the CftrtmiEUR/ F508del mouse model on a FVB background has reduced beta cell mass (Fontes et al. 2015). We confirmed these data using the Cftrtm1eur/F508del mouse model on a C57BL/6J background (Fig. 1D). These congruent data suggest that the phenotype links to the mutation in Cftr and not to the genetic background of the strain to which the Cftrm1eur/F508del was crossed. In addition to the previous observation we found that, the number of beta cells within each islet was similar between WT and F508del mice; suggesting that the reduced beta cell area is mainly due to smaller beta cells. Indeed, estimation of the beta cell size confirms this notion, and the beta cell area was on average $\sim 20 \%$ smaller compared to the area in WT beta cells (Fig. 1C). From the area, we can estimate the beta cell radius $(r)$ to be 5.3 and $4.8 \mu \mathrm{m}$ in WT and F508del beta cells, respectively. Although the volume density of granules $\left(N_{\mathrm{v}}\right)$ was similar, an estimate of the total number of granules $\left(N_{\mathrm{v}} \times\right.$ beta cell volume) suggest that each beta cell contains approximately $\sim 13,300$ granules and $\sim 10,500$ granules in WT and F508del mice, respectively. Thus, F508del beta cells have $20 \%$ less granules than the WT beta cells. Indeed, we measured a reduced insulin content in F508del islets (Supplementary Fig. 3A). The reduced beta cell size might be congenital with obstructed beta cell differentiation (Zertal-Zidani et al. 2013) and reduction in insulin granules or changes in cellular osmosis due to aberrant $\mathrm{Cl}^{-}$conductance (Miley et al. 1998).

Individuals with $\mathrm{CF}$ have dysregulated glucagon secretion displayed as postprandial hyperglycemia and contradictory failure to suppress glucagon secretion. The severity of the latter increases along with worsened glucose intolerance (Moran et al. 1991, Lanng et al. 1993, Lanng 2001). Also, glucagon secretion stimulated by insulin induced hypoglycemia was decreased in both CFRD and CF patients with normal glucose tolerance (Moran et al. 1991). Serum glucagon was threefold higher in F508del mice, suggesting signs of defective mechanisms to suppress glucagon secretion. Indeed, high glucose concentrations failed to suppress in vitro glucagon secretion in F508del islets. Interestingly, the amount of glucagon secreted (in presence of cAMP) from F508del islets during $15 \mathrm{~min}$ and $1 \mathrm{~h}$ was similar (Fig. $4 \mathrm{~A}, \mathrm{~B}$ and C), suggesting a lower maximal capacity in F508del alpha cells. For longer stimulation, the F508del alpha cells reach their full activity already in the presence of low glucose alone and addition of forskolin has a minor effect on amplification. We recently published that CFTR is important for glucagon secretion in human and mouse alpha cells (Edlund et al. 2017). The elevated glucagon secretion in F508del islets measured here is in agreement with our current hypothesis that CFTR is involved in the regulation of alpha cell action potential firing (Edlund et al. 2017), recently also supported by others (Huang et al. 2017). Hence, in addition to the defective insulin secretion caused by the F508del mutation, our data provide insights to why CF patients have defective glucagon counter-regulation.

Somatostatin secretion by delta cells was abnormal in the F508del islets (Fig. 4E and F). Delta cells release somatostatin with increased glucose concentration. Somatostatin receptors are present on both alpha and beta cells and binding of somatostatin inhibits adenylate cyclase, activates inwardly rectifying $\mathrm{K}^{+}$channels and/or inhibits $\mathrm{Ca}^{2+}$ channels (Kailey et al. 2012, Brereton et al. 2015). Somatostatin is an important paracrine regulator of insulin and is believed to prevent over-secretion of insulin (Brereton et al. 2015). Glucagon secretion is also inhibited by somatostatin (Briant et al. 2018). Presence of CFTR in rodent delta cells is unclear. Paracrine effects are likely to contribute to the increased somatostatin secretion. Glucagon has been shown to stimulate somatostatin secretion (Brunicardi et al. 2001). In F508del mice, both glucagon and somatostatin secretion is elevated so it is

This work is licensed under a Creative Commons Attribution 4.0 Unported License. 
possible that the elevated glucagon secretion stimulates somatostatin secretion. Another option is that the increased somatostatin secretion in F508del is explained by altered function of the beta cell. Recently it was shown that depolarization of the beta cells spreads via gap junctions to delta cells causing release of somatostatin and inhibition of glucagon secretion (Briant et al. 2018). Moreover, hormone release in the islets is pulsatile and driven by $\mathrm{Ca}^{2+}$ oscillations (Gylfe \& Tengholm 2014). The oscillations in $\mathrm{Ca}^{2+}$ have been shown to be disrupted by inhibition of $\mathrm{Cl}^{-}$influx using DIDS, which instead causes a steady increase in $\mathrm{Ca}^{2+}$ (Eberhardson et al. 2000). Considering that CFTR is a $\mathrm{Cl}^{-}$channel it is likely that mutations in Cftr can cause disruption in $\mathrm{Cl}^{-}$homeostasis and disturbances in the intricate paracrine network. The exact mechanism of how the paracrine network is regulated in F508del mice is not fully elucidated and needs further investigation.

\section{Conclusion}

Taken together, the F508del mutation in Cftr has consequences for alpha and beta cell function in vitro and in vivo. The observed defects in the regulation of insulin secretion associated with the F508del mutation become most apparent during cAMP-dependent stimulation. In conclusion, we suggest that presence of F508del mutation will cause (1) reduced exocytosis in beta cells, pointing toward reduced first-phase insulin secretion, (2) elevated release of proinsulin, suggesting defects in the insulin maturation process and (3) alpha cell hypersecretion of glucagon. Our results provide new insight in CFRD and suggest dysfunctional hormone secretion due to alpha and beta cell defects as part of the disease mechanism.

\section{Supplementary data}

This is linked to the online version of the paper at https://doi.org/10.1530/ JOE-18-0570.

\section{Declaration of interest}

The authors declare that there is no conflict of interest that could be perceived as prejudicing the impartiality of the research reported.

\section{Funding}

We acknowledge the support from the Swedish Foundation for Strategic Research (IRC-LUDC, SSF-IRC-LUDC), the Swedish Research Council (project grants to L E (2016-02124) and N W (K2013-99X 22243-01-5), and strategic research grant to EXODIAB (2009-1039)), CF-Trust SRCCFRD 007, ALF-Skåne (ALFSKANE-450661), Albert Påhlsson Foundation, The Royal Physiographical Society in Lund, O E and Edla Johanssons Scientific Foundation, Foundation Lars Hierta's Memory, Fredrik o Ingrid Thurings foundation, Erica Lederhausens Minnesstiftelse, Riksförbundet Cystisk Fibros, The Swedish Diabetes Foundation (DIA2016-130), Diabetes Wellness Network Foundation Sweden, The Novo Nordisk Foundation, EFSD-Boehringer Ingelheim Basic Research Program. A E's position as postdoc is funded by CF-Trust (SRC-CFRD 007).

\section{Author contribution statement}

A E, M F-T and L E designed the study. A E, M B, M H, I G M, M A, J S E E, E $\mathrm{S}, \mathrm{A}$ W, E R, E Z and N W participated in acquisition and analysis of data. A E, M F-T and L E participated in interpretation of data. B J S contributed with animal model. A E and L E drafted the manuscript. All authors revised the manuscript for important intellectual content and approved the final version. $L E$ is the guarantor of this work.

\section{Acknowledgements}

We thank Britt-Marie Nilsson and Anna-Maria Veljanovska-Ramsay for technical assistance.

\section{References}

Andersson SA, Pedersen MG, Vikman J \& Eliasson L 2011 Glucosedependent docking and SNARE protein-mediated exocytosis in mouse pancreatic alpha-cell. Pflugers Archiv 462 443-454. (https://doi. org/10.1007/s00424-011-0979-5)

Backhed F, Ding H, Wang T, Hooper LV, Koh GY, Nagy A, Semenkovich CF \& Gordon JI 2004 The gut microbiota as an environmental factor that regulates fat storage. PNAS 101 15718-15723. (https://doi. org/10.1073/pnas.0407076101)

Barg S, Huang P, Eliasson L, Nelson DJ, Obermuller S, Rorsman P, Thevenod F \& Renstrom E 2001 Priming of insulin granules for exocytosis by granular $\mathrm{Cl}(-)$ uptake and acidification. Journal of Cell Science 114 2145-2154.

Baron M, Veres A, Wolock SL, Faust AL, Gaujoux R, Vetere A, Ryu JH, Wagner BK, Shen-Orr SS, Klein AM, et al. 2016 A single-cell transcriptomic map of the human and mouse pancreas reveals interand intra-cell population structure. Cell Systems 3 340.e344-360.e344. (https://doi.org/10.1016/j.cels.2016.08.011)

Bellin MD, Laguna T, Leschyshyn J, Regelmann W, Dunitz J, Billings J \& Moran A 2013 Insulin secretion improves in cystic fibrosis following ivacaftor correction of CFTR: a small pilot study. Pediatric Diabetes 14 417-421. (https://doi.org/10.1111/pedi.12026)

Blodgett DM, Nowosielska A, Afik S, Pechhold S, Cura AJ, Kennedy NJ, Kim S, Kucukural A, Davis RJ, Kent SC, et al. 2015 Novel observations from next-generation RNA sequencing of highly purified human adult and fetal islet cell subsets. Diabetes 64 3172-3181. (https://doi. org/10.2337/db15-0039)

Boom A, Lybaert P, Pollet JF, Jacobs P, Jijakli H, Golstein PE, Sener A, Malaisse WJ \& Beauwens R 2007 Expression and localization of cystic fibrosis transmembrane conductance regulator in the rat endocrine pancreas. Endocrine 32 197-205. (https://doi.org/10.1007/s12020007-9026-x)

Brennan AL, Geddes DM, Gyi KM \& Baker EH 2004 Clinical importance of cystic fibrosis-related diabetes. Journal of Cystic Fibrosis 3 209-222. (https://doi.org/10.1016/j.jcf.2004.08.001) 
Brereton MF, Vergari E, Zhang Q \& Clark A 2015 Alpha-, delta- and PP-cells: are they the architectural cornerstones of islet structure and co-ordination? Journal of Histochemistry and Cytochemistry 63 575-591. (https://doi.org/10.1369/0022155415583535)

Briant LJB, Reinbothe TM, Spiliotis I, Miranda C, Rodriguez B \& Rorsman P 2018 Delta-cells and beta-cells are electrically coupled and regulate alpha-cell activity via somatostatin. Journal of Physiology $\mathbf{5 9 6}$ 197-215. (https://doi.org/10.1113/JP274581)

Brunicardi FC, Kleinman R, Moldovan S, Nguyen TH, Watt PC, Walsh J \& Gingerich R 2001 Immunoneutralization of somatostatin, insulin, and glucagon causes alterations in islet cell secretion in the isolated perfused human pancreas. Pancreas 23 302-308. (https://doi. org/10.1097/00006676-200110000-00012)

Cano Megias M, Gonzalez Albarran O, Guisado Vasco P, Lamas Ferreiro A \& Maiz Carro L 2015 Insulin resistance, beta-cell dysfunction and differences in curves of plasma glucose and insulin in the intermediate points of the standard glucose tolerance test in adults with cystic fibrosis. Endocrinologia y Nutricion 62 91-99. (https://doi. org/10.1016/j.endonu.2014.08.002)

Carvalho-Oliveira I, Efthymiadou A, Malho R, Nogueira P, Tzetis M, Kanavakis E, Amaral MD \& Penque D 2004 CFTR localization in native airway cells and cell lines expressing wild-type or F508del-CFTR by a panel of different antibodies. Journal of Histochemistry and Cytochemistry 52 193-203. (https://doi. org/10.1177/002215540405200207)

Chen JH, Stoltz DA, Karp PH, Ernst SE, Pezzulo AA, Moninger TO, Rector MV, Reznikov LR, Launspach JL, Chaloner K, et al. 2010 Loss of anion transport without increased sodium absorption characterizes newborn porcine cystic fibrosis airway epithelia. Cell 143 911-923. (https://doi.org/10.1016/j.cell.2010.11.029)

Daniel S, Noda M, Straub SG \& Sharp GW 1999 Identification of the docked granule pool responsible for the first phase of glucosestimulated insulin secretion. Diabetes 48 1686-1690. (https://doi. org/10.2337/diabetes.48.9.1686)

Davidson HW, Rhodes CJ \& Hutton JC 1988 Intraorganellar calcium and $\mathrm{pH}$ control proinsulin cleavage in the pancreatic beta cell via two distinct site-specific endopeptidases. Nature 333 93-96. (https://doi. org/10.1038/333093a0)

de Heer J, Rasmussen C, Coy DH \& Holst JJ 2008 Glucagon-like peptide-1, but not glucose-dependent insulinotropic peptide, inhibits glucagon secretion via somatostatin (receptor subtype 2 ) in the perfused rat pancreas. Diabetologia 51 2263-2270. (https://doi.org/10.1007/ s00125-008-1149-y)

De Marinis YZ, Salehi A, Ward CE, Zhang Q, Abdulkader F, Bengtsson M, Braha O, Braun M, Ramracheya R, Amisten S, et al. 2010 GLP-1 inhibits and adrenaline stimulates glucagon release by differential modulation of $\mathrm{N}$ - and L-type Ca2+ channel-dependent exocytosis. Cell Metabolism 11 543-553. (https://doi.org/10.1016/j. cmet.2010.04.007)

de Valk HW \& van der Graaf EA 2007 Cystic fibrosis-related diabetes in adults: where can we go from here? Review of Diabetic Studies 4 6-12. (https://doi.org/10.1900/RDS.2007.4.6)

Dobson L \& Sheldon CD \& Hattersley AT 2004 Understanding cysticfibrosis-related diabetes: best thought of as insulin deficiency? Journal of the Royal Society of Medicine 97 (Supplement 44) 26-35. (https://doi. org/10.1177/014107680409700107)

Eberhardson M, Patterson S \& Grapengiesser E 2000 Microfluorometric analysis of Cl- permeability and its relation to oscillatory Ca2+ signalling in glucose-stimulated pancreatic beta-cells. Cellular Signalling 12 781-786. (https://doi.org/10.1016/S08986568(00)00122-4)

Edlund A, Esguerra JL, Wendt A, Flodstrom-Tullberg M \& Eliasson L 2014 CFTR and anoctamin 1 (ANO1) contribute to cAMP amplified exocytosis and insulin secretion in human and murine pancreatic beta-cells. BMC Medicine 12 87. (https://doi.org/10.1186/1741 -7015-12-87)
Edlund A, Pedersen MG, Lindqvist A, Wierup N, Flodstrom-Tullberg M \& Eliasson L 2017 CFTR is involved in the regulation of glucagon secretion in human and rodent alpha cells. Scientific Reports 790 (https://doi.org/10.1038/s41598-017-00098-8)

Eliasson L, Renstrom E, Ding WG, Proks P \& Rorsman P 1997 Rapid ATP-dependent priming of secretory granules precedes $\mathrm{Ca}(2+)-$ induced exocytosis in mouse pancreatic B-cells. Journal of Physiology 503 399-412. (https://doi.org/10.1111/j.1469-7793.1997.399bh.x)

Eliasson L, Ma X, Renstrom E, Barg S, Berggren PO, Galvanovskis J, Gromada J, Jing X, Lundquist I, Salehi A, et al. 2003 SUR1 regulates PKA-independent cAMP-induced granule priming in mouse pancreatic B-cells. Journal of General Physiology 121 181-197. (https:// doi.org/10.1085/jgp.20028707)

Fontes G, Ghislain J, Benterki I, Zarrouki B, Trudel D, Berthiaume Y \& Poitout V 2015 The $\Delta$ F508 mutation in the cystic fibrosis transmembrane conductance regulator is associated with progressive insulin resistance and decreased functional beta-cell mass in mice. Diabetes 64 4112-4122. (https://doi.org/10.2337/db14-0810)

French PJ, van Doorninck JH, Peters RH, Verbeek E, Ameen NA, Marino CR, de Jonge HR, Bijman J \& Scholte BJ 1996 A delta F508 mutation in mouse cystic fibrosis transmembrane conductance regulator results in a temperature-sensitive processing defect in vivo. Journal of Clinical Investigation 98 1304-1312. (https://doi. org/10.1172/JCI118917)

Gerber PP, Trimble ER, Wollheim CB, Renold AE \& Miller RE 1981 Glucose and cyclic AMP as stimulators of somatostatin and insulin secretion from the isolated, perfused rat pancreas: a quantitative study. Diabetes 30 40-44. (https://doi.org/10.2337/diab.30.1.40)

Gibson-Corley KN, Meyerholz DK \& Engelhardt JF 2015 Pancreatic pathophysiology in cystic fibrosis. Journal of Pathology 238 311-320.

Gopel SO, Kanno T, Barg S, Weng XG, Gromada J \& Rorsman P 2000 Regulation of glucagon release in mouse-cells by KATP channels and inactivation of TTX-sensitive $\mathrm{Na}+$ channels. Journal of Physiology $\mathbf{5 2 8}$ 509-520. (https://doi.org/10.1111/j.1469-7793.2000.00509.x)

Guo JH, Chen H, Ruan YC, Zhang XL, Zhang XH, Fok KL, Tsang LL, Yu MK, Huang WQ, Sun X, et al. 2014 Glucose-induced electrical activities and insulin secretion in pancreatic islet beta-cells are modulated by CFTR. Nature Communications 5 4420. (https://doi. org/10.1038/ncomms5420)

Gylfe E \& Tengholm A 2014 Neurotransmitter control of islet hormone pulsatility. Diabetes, Obesity and Metabolism 16 (Supplement 1) 102-110. (https://doi.org/10.1111/dom.12345)

Hamdi I, Green M, Shneerson JM, Palmer CR \& Hales CN 1993 Proinsulin, proinsulin intermediate and insulin in cystic fibrosis. Clinical Endocrinology 39 21-26. (https://doi. $\operatorname{org} / 10.1111 /$ j.1365-2265.1993.tb01746.x)

Hardin DS, Ahn C, Rice J, Rice M \& Rosenblatt R 2008 Elevated gluconeogenesis and lack of suppression by insulin contribute to cystic fibrosis-related diabetes. Journal of Investigative Medicine $\mathbf{5 6}$ 567-573. (https://doi.org/10.2310/JIM.0b013e3181671788)

Hart NJ, Aramandla R, Poffenberger G, Fayolle C, Thames AH, Bautista A, Spigelman AF, Babon JAB, DeNicola ME, Dadi PK, et al. 2018 Cystic fibrosis-related diabetes is caused by islet loss and inflammation. JCI Insight 3 98240. (https://doi.org/10.1172/jci.insight.98240)

Hartling SG, Garne S, Binder C, Heilmann C, Petersen W, Petersen KE \& Koch C 1988 Proinsulin, insulin, and C-peptide in cystic fibrosis after an oral glucose tolerance test. Diabetes Research 7 165-169.

Huang WQ, Guo JH, Zhang XH, Yu MK, Chung YW, Ruan YC \& Chan HC 2017 Glucose-sensitive CFTR suppresses glucagon Secretion by potentiating KATP channels in pancreatic islet alpha cells. Endocrinology 158 3188-3199. (https://doi.org/10.1210/ en.2017-00282)

Johnston NR, Mitchell RK, Haythorne E, Pessoa MP, Semplici F, Ferrer J, Piemonti L, Marchetti P, Bugliani M, Bosco D, et al. 2016 Beta cell hubs dictate pancreatic islet responses to glucose. Cell Metabolism 24 389-401. (https://doi.org/10.1016/j.cmet.2016.06.020)

This work is licensed under a Creative Commons Attribution 4.0 Unported License. 
Kailey B, van de Bunt M, Cheley S, Johnson PR, MacDonald PE, Gloyn AL, Rorsman P \& Braun M 2012 SSTR2 is the functionally dominant somatostatin receptor in human pancreatic betaand alpha-cells. American Journal of Physiology: Endocrinology and Metabolism 303 E1107-E1116. (https://doi.org/10.1152/ ajpendo.00207.2012)

Kelly A, De Leon DD, Sheikh S, Camburn D, Kubrak C, Peleckis AJ, Stefanovski D, Hadjiliadis D, Rickels MR \& Rubenstein RC 2019 Islet hormone and incretin secretion in cystic fibrosis following 4-months of ivacaftor therapy. American Journal of Respiratory and Critical Care Medicine 199 342-351. (https://doi.org/10.1164/rccm.201806-1018OC)

Koivula FNM, McClenaghan NH, Harper AGS \& Kelly C 2016 Isletintrinsic effects of CFTR mutation. Diabetologia 59 1350-1355. (https://doi.org/10.1007/s00125-016-3936-1)

Lanng S 2001 Glucose intolerance in cystic fibrosis patients. Paediatric Respiratory Reviews 2 253-259. (https://doi.org/10.1053/ prrv.2001.0148)

Lanng S, Thorsteinsson B, Roder ME, Orskov C, Holst JJ, Nerup J \& Koch C 1993 Pancreas and gut hormone responses to oral glucose and intravenous glucagon in cystic fibrosis patients with normal, impaired, and diabetic glucose tolerance. Acta Endocrinologica 128 207-214. (https://doi.org/10.1530/acta.0.1280207)

Miley HE, Holden D, Grint R, Best L \& Brown PD 1998 Regulatory volume increase in rat pancreatic beta-cells. Pflugers Archiv $\mathbf{4 3 5}$ 227-230.

Moran A, Diem P, Klein DJ, Levitt MD \& Robertson RP 1991 Pancreatic endocrine function in cystic fibrosis. Journal of Pediatrics 118 715-723. (https://doi.org/10.1016/S0022-3476(05)80032-0)

Moran A, Becker D, Casella SJ, Gottlieb PA, Kirkman MS, Marshall BC, Slovis B \& CFRD Consensus Conference Committee 2010 Epidemiology, pathophysiology, and prognostic implications of cystic fibrosis-related diabetes: a technical review. Diabetes Care $\mathbf{3 3}$ 2677-2683. (https://doi.org/10.2337/dc10-1279)

Nyirjesy SC, Sheikh S, Hadjiliadis D, De Leon DD, Peleckis AJ, Eiel JN, Kubrak C, Stefanovski D, Rubenstein RC, Rickels MR, et al. 2018 $\beta$-Cell secretory defects are present in pancreatic insufficient cystic fibrosis with 1-hour oral glucose tolerance test glucose $\geq 155 \mathrm{mg} / \mathrm{dL}$. Pediatric Diabetes 19 1173-1182. (https://doi.org/10.1111/pedi.12700)

Ohlsson L, Hjelte L, Huhn M, Scholte BJ, Wilke M, Flodstrom-Tullberg M \& Nilsson A 2008 Expression of intestinal and lung alkaline sphingomyelinase and neutral ceramidase in cystic fibrosis f508del transgenic mice. Journal of Pediatric Gastroenterology and Nutrition $\mathbf{4 7}$ 547-554. (https://doi.org/10.1097/MPG.0b013e3181826daf)

Olivier AK, Yi Y, Sun X, Sui H, Liang B, Hu S, Xie W, Fisher JT, Keiser NW, Lei D, et al. 2012 Abnormal endocrine pancreas function at birth in cystic fibrosis ferrets. Journal of Clinical Investigation 122 3755-3768. (https://doi.org/10.1172/JCI60610)

Olofsson CS, Gopel SO, Barg S, Galvanovskis J, Ma X, Salehi A, Rorsman P \& Eliasson L 2002 Fast insulin secretion reflects exocytosis of docked granules in mouse pancreatic B-cells. Pflugers Archiv 444 43-51. (https://doi.org/10.1007/s00424-002-0781-5)

Seaquist ER, Kahn SE, Clark PM, Hales CN, Porte D Jr \& Robertson RP 1996 Hyperproinsulinemia is associated with increased beta cell demand after hemipancreatectomy in humans. Journal of Clinical Investigation 97 455-460. (https://doi.org/10.1172/JCI118435)

Segerstolpe Å, Palasantza A, Eliasson P, Andersson EM, Andreasson AC, Sun X, Picelli S, Sabirsh A, Clausen M, Bjursell MK, et al. 2016 Single-cell transcriptome profiling of human pancreatic islets in health and type 2 diabetes. Cell Metabolism 24 593-607. (https://doi. org/10.1016/j.cmet.2016.08.020)

Sheikh S, Gudipaty L, De Leon DD, Hadjiliadis D, Kubrak C, Rosenfeld NK, Nyirjesy SC, Pelekis AJ, Malik S, Stefanovski D, et al. 2017 Reduced beta-cell secretory capacity in pancreatic insufficient, but not pancreatic sufficient, cystic fibrosis despite normal glucose tolerance. Diabetes 66 134-144. (https://doi.org/10.2337/db16-0394)

Sheppard DN \& Welsh MJ 1999 Structure and function of the CFTR chloride channel. Physiological Reviews 79 S23-S45. (https://doi. org/10.1152/physrev.1999.79.1.S23)

Sun X, Yi Y, Xie W, Liang B, Winter MC, He N, Liu X, Luo M, Yang Y, Ode KL, et al. 2017 CFTR influences beta cell function and insulin secretion through non-cell autonomous exocrine-derived factors. Endocrinology 158 3325-3338. (https://doi.org/10.1210/en.201700187)

Uc A, Olivier AK, Griffin MA, Meyerholz DK, Yao J, Abu-El-Haija M, Buchanan KM, Vanegas Calderon OG, Abu-El-Haija M, Pezzulo AA, et al. 2015 Glycaemic regulation and insulin secretion are abnormal in cystic fibrosis pigs despite sparing of islet cell mass. Clinical Science 128 131-142. (https://doi.org/10.1042/CS20140059)

van Doorninck JH, French PJ, Verbeek E, Peters RH, Morreau H, Bijman J \& Scholte BJ 1995 A mouse model for the cystic fibrosis delta F508 mutation. EMBO Journal 14 4403-4411. (https://doi. org/10.1002/j.1460-2075.1995.tb00119.x)

Vikman J, Ma X, Hockerman GH, Rorsman P \& Eliasson L 2006 Antibody inhibition of synaptosomal protein of $25 \mathrm{kDa}$ (SNAP-25) and syntaxin 1 reduces rapid exocytosis in insulin-secreting cells. Journal of Molecular Endocrinology 36 503-515. (https://doi.org/10.1677/ jme.1.01978)

Wierup N, Kuhar M, Nilsson BO, Mulder H, Ekblad E \& Sundler F 2004 Cocaine- and amphetamine-regulated transcript (CART) is expressed in several islet cell types during rat development. Journal of Histochemistry and Cytochemistry 52 169-177. (https://doi. org/10.1177/002215540405200204)

Wilke M, Buijs-Offerman RM, Aarbiou J, Colledge WH, Sheppard DN, Touqui L, Bot A, Jorna H, de Jonge HR \& Scholte BJ 2011 Mouse models of cystic fibrosis: phenotypic analysis and research applications. Journal of Cystic Fibrosis 10 (Supplement 2) S152-S171. (https://doi.org/10.1016/S1569-1993(11)60020-9)

Wooldridge JL, Szczesniak RD, Fenchel MC \& Elder DA 2015 Insulin secretion abnormalities in exocrine pancreatic sufficient cystic fibrosis patients. Journal of Cystic Fibrosis 14 792-797. (https://doi. org/10.1016/j.jcf.2015.02.009)

Zertal-Zidani S, Busiah K, Edelman A, Polak M \& Scharfmann R 2013 Small-molecule inhibitors of the cystic fibrosis transmembrane conductance regulator increase pancreatic endocrine cell development in rat and mouse. Diabetologia 56 330-339. (https://doi. org/10.1007/s00125-012-2778-8)

Received in final form 15 December 2018

Accepted 5 February 2019

Accepted Preprint published online 5 February 2019 https://joe.bioscientifica.com https://doi.org/10.1530/JOE-18-0570 (c) 2019 The authors Published by Bioscientifica Ltd. Printed in Great Britain

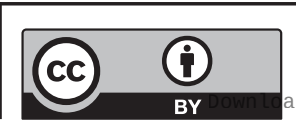

This work is licensed under a Creative Commons Attribution 4.0 Unported License. 